\title{
Electrocoagulation Degradation of Oily Wastewater by Using Al-based Amorphous Alloy
}

\author{
Xiao Chen $\mathrm{Xu}^{1,2}$, Ke Qiang Qiu ${ }^{1, *}$ \\ ${ }^{1}$ Material Science and Engineering College, Shenyang University of Technology, Shenyang, China \\ ${ }^{2}$ Mechanical and Power Engineering College, Yingkou Institute of Technology, Yingkou,, China
}

Email address:

kqqiu@163.com (Ke Qiang Qiu)

${ }^{*}$ Corresponding author

To cite this article:

Xiao Chen Xu, Ke Qiang Qiu. Electrocoagulation Degradation of Oily Wastewater by Using Al-based Amorphous Alloy. Engineering Science. Vol. 6, No. 1, 2021, pp. 12-16. doi: 10.11648/j.es.20210601.12

Received: February 3, 2021; Accepted: February 10, 2021; Published: February 27, 2021

\begin{abstract}
Oily wastewater is proven to be common both in industry and home life. A particular contaminant of concern is petroleum hydrocarbon present in various types of wastewater comingfrom shipyards, onshore and offshore industries, and engine rooms of ships. As the standards for oily wastewater treatment become more and more strict, and emulsified oil wastewater is characterized by difficult degradation and high toxicity, we adopt the electrocoagulation technology with $\mathrm{Al}_{86} \mathrm{Ni}_{10} \mathrm{Y}_{4}$ amorphous alloy as anode and graphite as cathode to treat it to surpass the limitations of conventional methods. The degradation effect on the oily wastewater was characterized by chemical demand oxygen (COD), while the ribbons before and after using were analyzed by $\mathrm{X}$-ray diffraction (XRD) and scanning electron microscope (SEM) The results show that when the $\mathrm{pH}$ value is 3 and the current density is $6.5 \mathrm{~mA} / \mathrm{cm}^{2}$, the COD removal rate can reach to $75.68 \%$ within 100 minutes. Large areas of white corrosion products appear on the surface of the Al-based amorphous alloy after reaction. These protrusions are mainly formed by anodic oxidation corrosion of Al-based amorphous alloy. So, the electrocoagulation technology with amorphous alloy as anode and graphite as cathode is suitable for being utilized to treat the emulsified oil wastewater. And it will have a good practical application prospect.
\end{abstract}

Keywords: Al-based Amorphous Alloy, Electrocoagulation, Oil Wastewater, COD Removal Rate, Degradation

\section{Introduction}

With the development of industry and the transformation of manufacturing industry, a large amount of waste water with complex composition is discharged into the environment. Among them, oily wastewater is highly polluted and difficult to degrade, which brings great damage to people's health [1]. Generally speaking, the methods of wastewater treatment include physical method, biological method, chemical method, etc. The physical method is relatively simple in operation and low in energy consumption, but the degradation efficiency of pollutants is not high. Biological treatment has better effects and is easy to control, but the treatment time is longer and it is greatly affected by the natural environment. Chemical methods can achieve complete degradation of pollutants, but some chemical reagents need to be added and the cost is higher. Among them, the electrochemical method is particularly common. With the help of electric field, the electrochemical method has a relatively high degradation efficiency without adding other agents and does not produce secondary pollution. However, this method consumes a lot of energy and has safety problems. Oil wastewater exists in the form of a secondary oil-in-water emulsion, and contains a large number of surfactants that are difficult to be biodegraded [2]. It is difficult to achieve oil-water separation by conventional physical methods. Electrocoagulation is a comprehensive method of flocculation, stripping and other mechanisms, that is, under the action of an electric field, the soluble anode is dissolved to form a flocculant, which absorbs oil particles, and at the same time produces hydrogen at the cathode, which will remove the oil in the water by sedimentation or floating [3-6]. The method has the advantages of wide application range, excellent treatment effect, simple and compact structure and easy operation. Electrocoagulation (EC) process has been shown to be an effective and reliable technology that provides an environmentally compatible method for reducing a large variety of pollutants [7, 8]. Gobbi et al. [9] used Al-based 
electrocoagulation technology to treat oily wastewater with a degradation efficiency of $98 \%$. Chen Guangguang [10] used electrocoagulation technology to treat petroleum wastewater, and the removal rate of wastewater turbidity was more than 95\%. Swati et al. [11] combined EC with electro-oxidation method in the treatment of sunflower oily wastewater and the high removal efficiency of $90-95 \%$ was achieved for the organic pollutant. While EC combined with aeration is also an effective way to increase removal efficiency of COD from $84 \%$ for the non-aerated cells to $93.3 \%$ for the aerated cells [12].

Amorphous alloy is a material with a special structure, with excellent properties, such as: corrosion resistance, magnetic properties, catalytic performance, etc., is one of the preferred electrode materials for electrochemical treatment technology. The amorphous alloy has more catalytic active centers because of its extremely disordered atomic arrangement, which makes its valence state in a highly coordinated unsaturated state. The application of amorphous alloy in wastewater treatment mainly focuses on printing and dyeing wastewater, but less in the treatment of emulsified oil wastewater. In order to further broaden the application of amorphous alloy as electrode in the field of electrochemistry Application scope. In this paper, $\mathrm{Al}_{86} \mathrm{Ni}_{10} \mathrm{Y}_{4}$ amorphous alloy is used as anode and graphite as cathode, oily wastewater is treated based on the electrocoagulation process, and COD removal rate is used as the main evaluation index. The effect of current density, initial $\mathrm{pH}$ value and other factors on the degradation reaction were mainly studied, and a new efficient and economic treatment technology was provided for the treatment of emulsified oil wastewater.

\section{Materials and Methods}

\subsection{Experimental Materials}

Simulation of oily wastewater (OW): Diesel oil and emulsifier were selected to simulate the $\mathrm{OW}$ in this experiment. Water, diesel oil and emulsifier OP-10 were mixed in a beaker at a ratio of 2000:5:2, stirred at a speed of $300 \mathrm{rad} / \mathrm{min}$, and diluted according to this ratio. Prepare simulated oily wastewater with an initial COD value of 374 $\mathrm{mg} / \mathrm{L}$ and kept away from light.

Preparation of $\mathrm{Al}_{86} \mathrm{Ni}_{10} \mathrm{Y}_{4}$ amorphous ribbon: $\mathrm{Al}, \mathrm{Ni}$ and $\mathrm{Y}$ with $99.99 \%$ purity were used as nominal ingredients. The parent alloy was smelted through vacuum induction arc furnace with a vacuum degree of $5.0 \times 10^{-3} \mathrm{~Pa}$, and then the amorphous alloy ribbon was prepared by strapping at a copper roll speed of $3800 \mathrm{rad} / \mathrm{min}$.

\subsection{Electrocoagulation experiments}

Took $400 \mathrm{ml}$ oily wastewater into the electrolytic cell, and adjusted the $\mathrm{pH}$ value of the wastewater with $1 \mathrm{~mol} / \mathrm{L} \mathrm{H}_{2} \mathrm{SO}_{4}$ or $1 \mathrm{~mol} / \mathrm{L} \mathrm{NaOH}$ solution. $60 \mathrm{~mm} \times 50 \mathrm{~mm} \quad \mathrm{Al}_{86} \mathrm{Ni}_{10} \mathrm{Y}_{4}$ amorphous ribbon as the anode and $60 \mathrm{~mm} \times 50 \mathrm{~mm} \times 5 \mathrm{~mm}$ graphite plate as the cathode, then connected with the direct power supply of model DP3005ET. The electrode spacing was $5 \mathrm{~cm}$. In order to improve the conductivity of the emulsified oil wastewater, $0.2 \mathrm{~g} / \mathrm{L} \mathrm{Na}_{2} \mathrm{SO}_{4}$ was added to the solution as an electrolyte, samples were taken every 10 minutes, and the COD value was measured after filtering through a filter paper with a pore size of $30-50 \mu \mathrm{m}$.

AL-2700 X-ray diffractometer (XRD) was used to characterize the amorphous structure. $\mathrm{Cu}-\mathrm{K} \alpha$ was used with scanning rate of $13^{\circ} / \mathrm{min}$, the scanning range is $5-85^{\circ}$, and the power was $4 \mathrm{~kW}$; Used Sigma 300 scanning electron microscope for surface morphology analysis and rapid digestion instrument PT593 for the determination of chemical oxygen demand (COD). The mixture of $\mathrm{HgSO}_{4}-\mathrm{H}_{2} \mathrm{SO}_{4}$, $\mathrm{Ag}_{2} \mathrm{SO}_{4}-\mathrm{H}_{2} \mathrm{SO}_{4}$ and $\mathrm{K}_{2} \mathrm{Cr}_{2} \mathrm{O}_{7}$ was added into the water sample to be determined, with the contents of $2 \mathrm{~mL}, 0.5 \mathrm{~mL}$ and $0.5 \mathrm{~mL}$ respectively. Then added these agents to a $2 \mathrm{~mL}$ wastewater sample and heated in a digester. Took it out after $2 \mathrm{~h}$. After digestion and cooling, put it into a spectrophotometer to measure the COD value of the wastewater.

The calculation formula of COD removal rate is shown in (1):

$$
\text { COD removal rate } \%=\frac{c_{0}-c_{t}}{c_{0}} \times 100 \%
$$

$\mathrm{C}_{\mathrm{t}}$ and $\mathrm{C}_{0}$ are the COD values of oil-bearing wastewater at the time of reaction $t$ and the initial time respectively, and the unit is $\mathrm{mg} / \mathrm{L}$.

\section{Results}

Ribbon characterization before and after $\mathrm{Al}_{86} \mathrm{Ni}_{10} \mathrm{Y}_{4}$ treatment of oily wastewater

Figure 1 shows the XRD spectrum of $\mathrm{Al}_{86} \mathrm{Ni}_{10} \mathrm{Y}_{4}$ amorphous alloy ribbons used in the wastewater (before \& after). From the diagram, we can see the X-ray diffraction pattern shows the typical diffuse peak of amorphous alloy at the point of in $2 \theta=30^{\circ}-40^{\circ}$. However, there is no obvious crystalline diffraction peak, indicating that the samples prepared are all amorphous structure. The $\mathrm{Al}_{86} \mathrm{Ni}_{10} \mathrm{Y}_{4}$ amorphous ribbon still maintains a good amorphous structure after the treatment of oil-bearing wastewater.

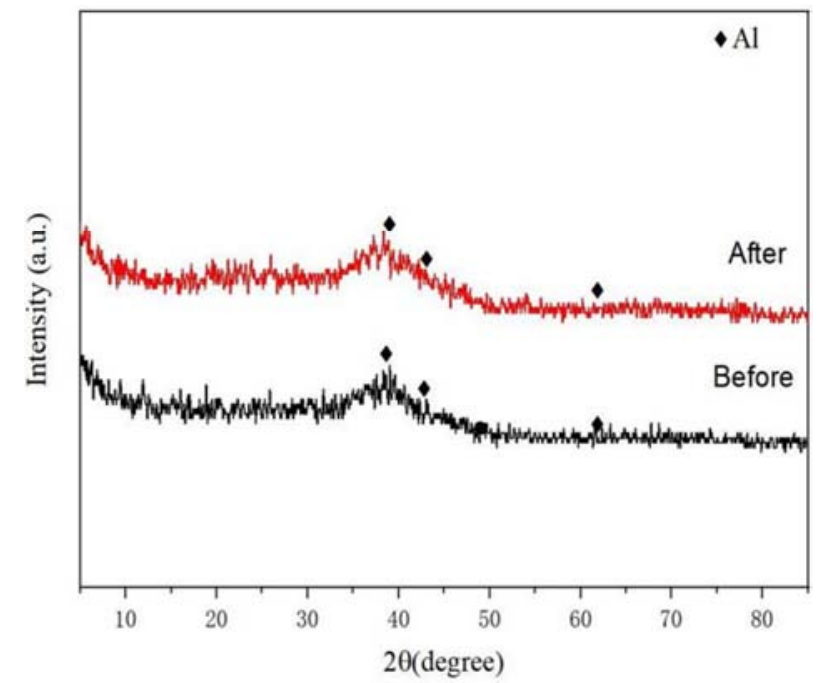

Figure 1. XRD patterns of $\mathrm{Al}_{86} \mathrm{Ni}_{10} \mathrm{Y}_{4}$ amorphous bands before and after degradation. 


\subsection{Effect of initial $\mathrm{pH}$ value}

Figure 2 shows the effects of different $\mathrm{pH}$ values on degradation effect. It shows that under different $\mathrm{pH}$ conditions, degradation effect becomes better and better with the extension of reaction time. The COD removal rate can reach over $72.38 \%$ in a lower $\mathrm{pH}$ range, but degradation effect decreases with the increase of $\mathrm{pH}$ value. This is because in the lower $\mathrm{pH}$ range, the main form of aluminum ion is the complex ions with high charge and low degree of polymerization. Finally, aluminum hydroxide is formed. These hydroxides and polymerized hydroxides have a strong adsorption on organic molecules, which is conducive to aggregation. Hydrogen can also aggregate into microbubbles to contact with pollutants and rise to the liquid surface to form a scum layer, which can degrade pollutants. However, with the continuous increase of $\mathrm{pH}$ value, some aluminum ion polymers will redissolve, resulting in the degradation effect decreasing [4].

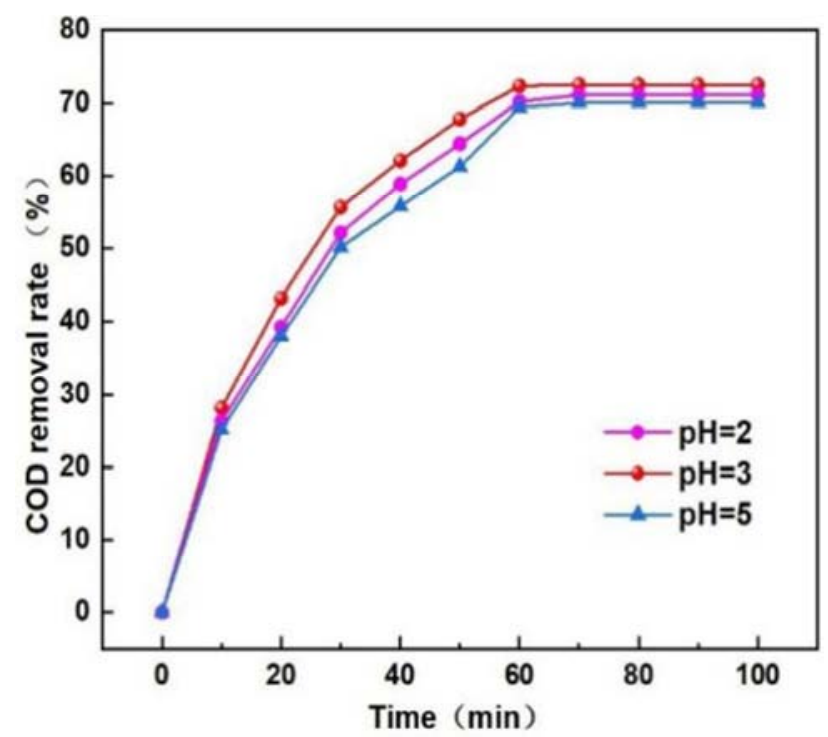

Figure 2. Effect of pH value on COD removal rate of oily wastewater.

\subsection{Effect of current density}

Figure 3 shows the relationship between current density and degradation efficiency. The current density is the most important factor for the photo degradation effect. The COD removal rate reaches the maximum when the current density is $6.5 \mathrm{~mA} / \mathrm{cm}^{2}$. As the current density increases to $9.0 \mathrm{~mA} / \mathrm{cm}^{2}$, the COD removal rate gradually decreases and eventually tends to remain unchanged. Through the above data analysis, it is concluded that when the reaction current density is 6.5 $\mathrm{mA} / \mathrm{cm}^{2}$, the removal rate of the simulated oil-bearing wastewater is the highest. If the current is too high, electron migration will occur between materials [10], reducing the removal effect. This is because when the current density is small, less $\mathrm{A}^{3+}$ is precipitated out of the amorphous gold ribbon, then the degradation efficiency is not high. When the current density increases, more and more aluminum ions will be dissolved, and the corresponding hydroxyl complexes will be increased, and the adsorption and flocculation of organic matter will be also increased, so that the COD removal rate increases. However, the removal rate is not high due to the small current density. This is because the generated products consume more $\mathrm{Al}_{86} \mathrm{Ni}_{10} \mathrm{Y}_{4}$ amorphous bands, thus reducing the degradation efficiency.

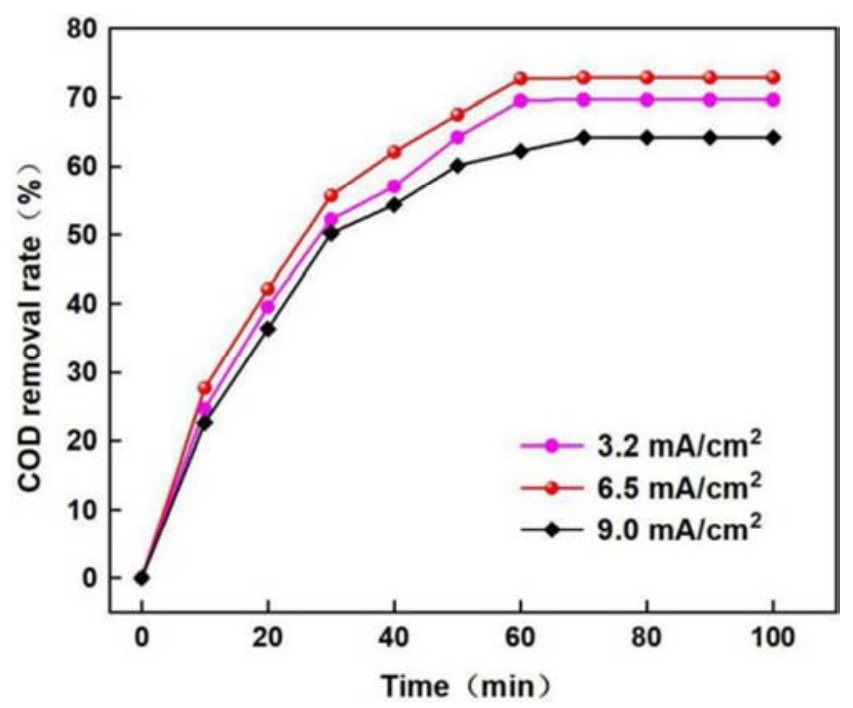

Figure 3. Effect of current density on COD removal rate.

\subsection{Surface Topography Analysis}

Figure 4 is to further explore the surface morphology and composition of aluminum-based amorphous before and after the treatment of emulsified oil wastewater. The SEM morphology was analyzed under the optimum reaction conditions. As can be clearly seen from Figure 4 (a), the surface of the Al-based amorphous alloy is smooth without cracks before the reaction. As shown in Figure 4 (b), a large area of white corrosion products appears on the surface of the Al-based amorphous alloy after reaction. As can be seen from the composition analysis figure (d), oxygen elements appeared after the treatment of wastewater by amorphous ribbon, and these protrusions are mainly formed by anodic oxidation and corrosion of Al-based amorphous alloy. Therefore, when $\mathrm{Al}_{86} \mathrm{Ni}_{10} \mathrm{Y}_{4}$ amorphous ribbon is used to degrade oily wastewater, a large number of reaction products are attached to the surface of the ribbon, and the possible reaction equations are shown in (2.1), (2.2), and (2.3).

$$
\begin{gathered}
\mathrm{A}^{3+}+\mathrm{H}_{2} \mathrm{O} \rightarrow \mathrm{A} 1(\mathrm{OH})^{2+}+\mathrm{H}^{+} \\
\mathrm{A} 1(\mathrm{OH})^{2+}+\mathrm{H}_{2} \mathrm{O}+\mathrm{O}_{2} \rightarrow \mathrm{A} 1(\mathrm{OH})_{2}^{+}+\mathrm{H}^{+} \\
\mathrm{A} 1(\mathrm{OH})_{2}^{+}+\mathrm{H}_{2} \mathrm{O} \rightarrow \mathrm{A} 1(\mathrm{OH})_{3}+\mathrm{H}^{+}
\end{gathered}
$$

So far, many researchers at home and abroad have used different electrode materials for electrochemical treatment of various wastewater. As shown in Table 1, the comparison with other research results shows that the treatment of simulated emulsified oil wastewater by using an amorphous alloy based on electrocoagulation technology is effective. 

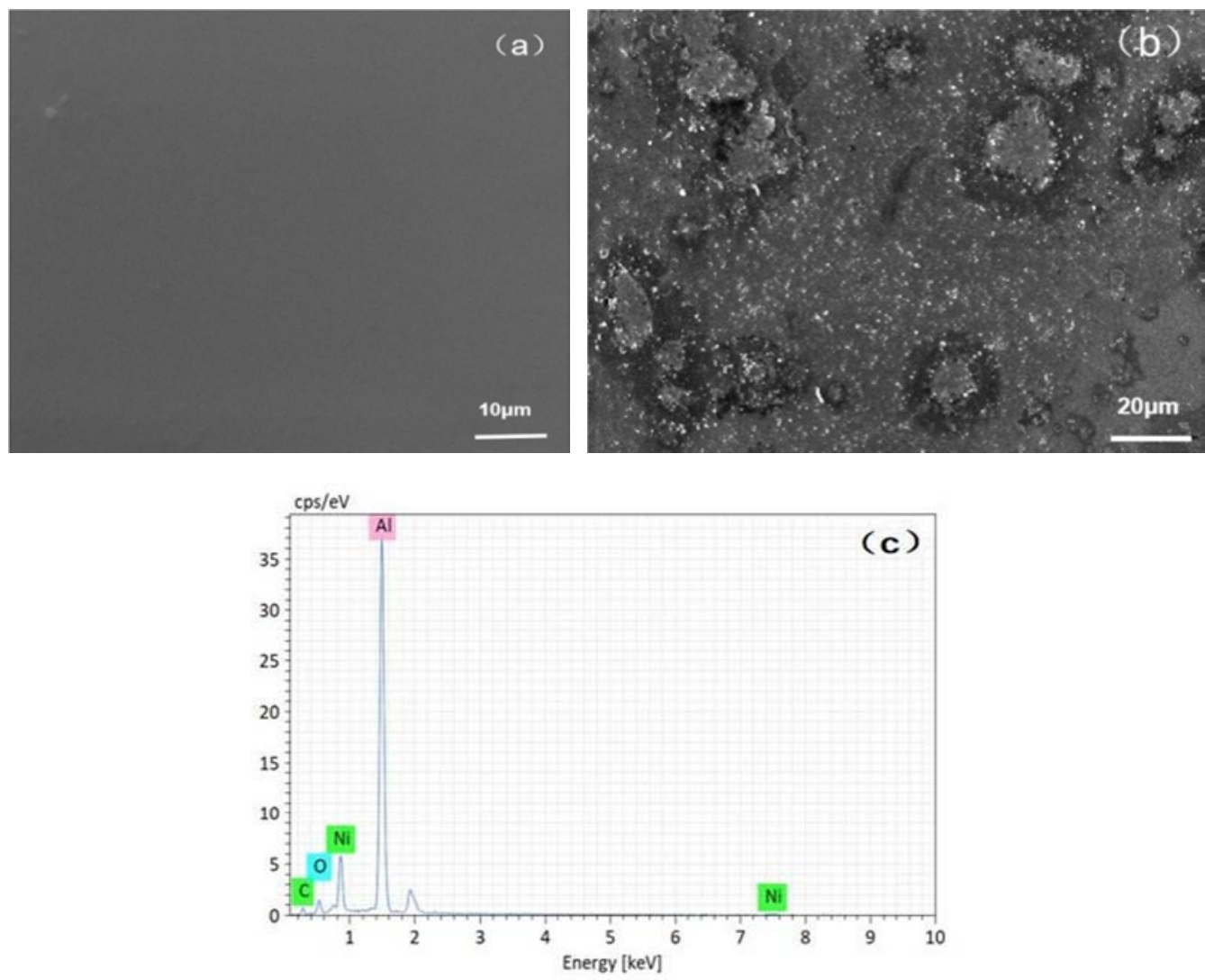

Figure 4. Surface morphology characteristics of $\mathrm{Al}_{86} \mathrm{Ni}_{10} \mathrm{Y}_{4}$ amorphous ribbons (a) Surface morphology of ribbons before reaction in wastewater and (b) after reaction (c) EDS composition analysis after reaction.

Table 1. Comparison Between Different Research Results.

\begin{tabular}{lllll}
\hline pollutant & Electrode (anode) & conditions & Removal rate (\%) & reference \\
\hline Emulsified oil wastewater & $\mathrm{Al}_{86} \mathrm{Ni}_{10} \mathrm{Y}_{4}$ amorphous & $\mathrm{pH}=3$, Current density $=6.5 \mathrm{~A} / \mathrm{m}^{2}$ & 75.68 & This work \\
Olive oil mill wastewater & $\mathrm{Fe}$ & $\mathrm{pH}=6.9$, current density $=3 \mathrm{~mA} / \mathrm{cm}^{2}$ & 62.7 & {$[13]$} \\
Petrochemical wastewater & $\mathrm{Stainless} \mathrm{steel}$ & $\mathrm{pH}=3$, current density $=0.6 \mathrm{~A} / \mathrm{m}^{2}$, & 50 & {$[14]$} \\
Dye wastewater & $\mathrm{Pt} / \mathrm{Ti}$ & $\mathrm{pH}=3$, current density $=68 \mathrm{~A} / \mathrm{m}^{2}$, & 70.6 & {$[15]$} \\
\hline
\end{tabular}

\section{Conclusions}

In the process of degradation of the simulated oily wastewater by the electrocoagulation technology with $\mathrm{Al}_{86} \mathrm{Ni}_{10} \mathrm{Y}_{4}$ amorphous alloy as anode and graphite plate as cathode, the effects of $\mathrm{pH}$ value and current density on the degradation were studied, and the following conclusions were obtained:

1) The optimal processing parameters include the $\mathrm{pH}$ value of 3 , the current density of $6.5 \mathrm{~mA} / \mathrm{cm}^{2}$, the COD removal rate within $100 \mathrm{~min}$ reaches $75.68 \%$

2) Large areas of white corrosion products appear on the surface of the Al-based amorphous alloy after reaction. These protrusions are mainly formed by anodic oxidation corrosion of Al-based amorphous alloy.

\section{Acknowledgements}

This work was supported by the Education Department of Liaoning Province (Grant No. 201724123). Natural Science Foundation of Liaoning Province (Grant No. 2019ZD0373).

\section{References}

[1] Poulopoulos S. G., Grigoropoulou H. P, et al. Stripping as a pretreatment process of industrial owastewater [J]. Journal of Hazardous Materials, 2005, 117 (3): 135-139.

[2] Guo R L, Shi Y, Wang Z Z. Research development on organics removal in reverse osmosis concentrates [J]. Technology of Water Treahnent, 2013, 39 (4): 1-14.

[3] Ahmadi S, Sardari E, et al. Removal of oil from biodiesel wastewater by electrocoagulation method [J]. The Korean Journal of Chemical Engineering, 2013, 30 (3): 634-641.

[4] Sravanth T, Ramesh ST, Gandhimathi R, Nidheesh PV Continuous treatability of oily wastewater from locomotive wash facilities by electrocoagulation. Sep Sci Technol [J]. 2020, 55 (3): 583-589.

[5] Daghrir R, Drogui P. Electrochemical treatment of domestic wastewater using boron-doped diamond and nanostructured amorphous carbon electrodes [J]. Environmental Science and Pollution Research, 2014, 21 (10): 6578-6589. 
[6] Boopathy R, Trupti D, et al. New approach of integrated advanced oxidation processes for the treatment of lube oil processing wastewater [J]. Arab J Sci Eng 2018, 43 (11): $6229-6236$

[7] Ahmadi S, Sardari E, Javadian HR, Katal R, Sefti MV. Removal of oil from biodiesel wastewater by electrocoagulation method. Korean J Chem Eng, 2013, 30 (3): 634-641.

[8] Ma X, Zhou M. A comparative study of azo dye decolorization by electro-Fenton in two common electrolytes. J Chem Technol Biotechnol, 2009, 84 (10): 1 544-1549.

[9] Gobbi L C A, Nascimento I L, Muniz E P, etal. Electrocoagulation with polarity switch for fast oil removal from oil in water emulsions [J]. Journal of Environmental Management, 2018, 13 (1): 119-125.

[10] Chen Guangguan, Hu Qi, et al. Electrocoagulation Treatment of Petroleum Cracking Catalyst Wastewater [J]. Journal of environmental engineering, 2015, 9 (10): 4850-4856.

[11] Swati S, Ahmet A, Halis S. Electrochemical treatment of sunflower oil refinery wastewater and optimization of the parameters using response surface methodology Chemosphere, 2020, 249: 126511.

[12] Khalifa O, Banat F, Srinivasakannan C, Radjenovic J, Hasan SW Performance tests and removal mechanisms of aerated electrocoagulation in the treatment of oily wastewater. J Water Pro Eng, 2020, 36: 101290.

[13] Flores N, Brillas E, Centellas F, etal. Treatment of olive oil mill wastewater by single electrocoagulation with different electrodes and sequential electrocoagulation/electrochemical Fenton-based processes [J]. Journal of Hazardous Materials, 2018, 347 (2): 58-66.

[14] Ting W. P., Huang Y. H., Lu M. C., Catalytic treatment of petrochemical wastewater by electro-assisted Fenton technologies [J]. React. Kinet. Catal. Lett, 2007, 92 (1): 41-48.

[15] Wang C. T., Hu J. L., etal, Removal of color from real dyeing wastewater by electro-Fenton technology using a three-dimensional graphite cathode [J] J Hazard, Mater. 2008, 152 (10): 601-606. 